\title{
Self-Perception of ABM Students towards Their Academic, Social and Emotional College Preparedness
}

\author{
Remedios P. Magnaye, DBA \\ Lyceum of the Philippines University, Batangas City, Philippines
}

\begin{abstract}
This study assessed the self-perception of the selected Accountancy, Business and Management (ABM) students on their academic, social and their emotional college preparedness. The students' demographic profile was also tested for significant difference in the three constructs of the college preparedness. Through a self-made questionnaire in a 4scale Likert style, data were gathered from the 255 randomly selected ABM students of one private higher education institution in Batangas Province in the Philippines. Self-perception showed a college-prepared student academically, socially and emotionally. However, there are various constructs of their academic and social-emotional preparedness that need further improvements. The statistical test of significance indicated that the various constructs of academic, social and emotional preparedness have no difference by age, type of school, family income and order of birth. A significant difference was shown in the respondents' sex and social preparedness but not on academic and emotional preparedness. Similarly, there was significant difference in the various constructs of academic, social and emotional preparedness in terms of the students' GWA in high school. For this, high schools should develop collaborative teaching and learning strategies focus on reading and writing. In addition, colleges and universities may provide pertinent course information through their websites to guide the students on the various details of their chosen undergraduate courses. Indeed, to prepare students for college alone is insufficient; a college-ready student should complete a degree with a life-ready perspectives.
\end{abstract}

Keywords: college-ready students, college preparedness, academic preparedness, social preparedness, emotional preparedness

Suggested Citation: Magnaye, R.P. (2020). Self-Perception of ABM Students towards Their Academic, Social and Emotional College Preparedness. International Journal of Educational Management and Development Studies, Volume 1, Issue 2, pp. 1- 18 


\section{Introduction}

The shift from high school to college can be a struggle even to high-achieving students due to lack of preparedness. According to Boden (2011), students entering college usually perceived their academic, social and emotional preparedness with feelings of insecurity and confusion. In a more challenging situation, uncertainties occur because undergraduate students enter their first year of college at different level of preparedness (DeAngelo \& Franke, 2016). In most of the cases, lack of preparedness led to withdrawal or dropping out from college. It is important then to know what college readiness is. According to Wignall (2020), it involves a set of skills, knowledge and behaviors that every high school student must achieve upon graduation. Grundmeyer (2012) adds that skills and knowledge makes students college-ready without remedial classwork.

The issue on college preparedness has been tossed to the higher education. As White (2016) posits that higher education don't consider themselves responsible. The fact that in the US alone more than $1 / 3$ of the college undergraduates never finish their degree. For Wignall (2020), there are common core subjects to develop a college-ready students such as math, language arts and science. These subjects prepare students with college-ready skills such as writing and speaking. Conley (2008) suggests that schools make use of the big four: cognitive strategies, content knowledge, self-management skills, and knowledge about postsecondary education in order to help students gain success in their college. Meanwhile, Duncheon (2015) summarized the college readiness in three broad categories which include cognitive academic factors, non-cognitive academic factors and campus integration factors.

According to a study cited by Levin (2019), high school students enter college unprepared. The US national survey conducted by the nonprofit YouthTruth revealed that only 45 percent of students were positive about their college readiness. In another study conducted by Jawad (2017), students perceived a limited ability to adjust to social demands. The identified key trends were: high school students want an explicit explanation on the 'why' of learning and its application in real-life situations and high school students want exposure to non-academic life skills. However, scenarios differ by country.

In the Philippines for instance, the introduction of the $\mathrm{K}$ to 12 programs promised a more prepared student for college. As per the Commission on Higher Education Memorandum Order 20, Series of 2013, high school students are expected to connect to the local, national 
INTERNATIONAL JOURNAL OF EDUCATIONAL MANAGEMENT AND

DEVELOPMENT STUDIES

Volume 1, Issue 2 • December 2020 • ISSN 2719-0633 (PRINT) 2719-0641 (ONLINE)

and global communities concerns and challenges. For instance, the Accountancy, Business and Management program expects students to communicate effectively, analyze business problems and opportunities, make good decisions and develop positive ethical perception on local and global business competitions. While students are expected to have proper study habit, plenty of hard work and inquisitive mind to finish the degree, getting admission is easier than progression in the program. Shortcomings are highly observed.

This study intended to find out the self-perception of the first year college students in their academic, social and emotional preparedness in pursuing the Accountancy, Business and Management track. The college readiness was self-assessed by selected students in three areas: academic, social and emotional. Furthermore, the level of preparedness was statistically signified by their demographic profiles including age, sex, type of school, general weighted average, family income and order of birth. Thus, the study tested the following hypothesis:

HO1: There is no significant difference in the level of students' academic, social and emotional preparedness when grouped according to their demographic profile

\section{Literature Review}

\subsection{Models on college and career preparedness}

The current study is deeply rooted on the model of college readiness postulated by Conley \& French (2014). The model emphasizes on the four key areas to develop college and career readiness of the students: key cognitive strategies, key content knowledge, key transition knowledge and skills and key learning skills and techniques. Each key has specific constructs that students need to develop. Van Rooij (2018), emphasizes that cognitive strategies are the ways of thinking and working required in postsecondary learning environment, content knowledge refers to the core subjects' knowledge and skills, learning skills and techniques consist of academic behaviors and beliefs and transition knowledge and skills refer to the information and skills to start a degree. 


\section{Figure 1}

Conley's model of college and career readiness

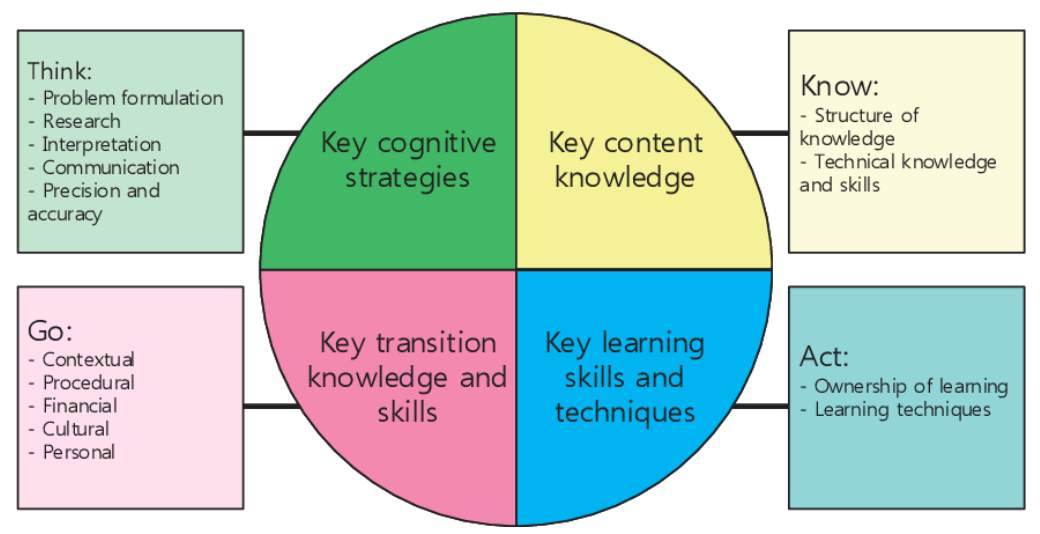

Source: Conley \& French (2014)

The other conceptual background the current study was founded is the new foundation of readiness authored by Prince, Saveri \& Swanson (2017). The model pointed that the social-emotional skills as the core of future readiness. These skills are necessary for the career readiness of the students.

\section{Figure 2}

The new foundation for readiness

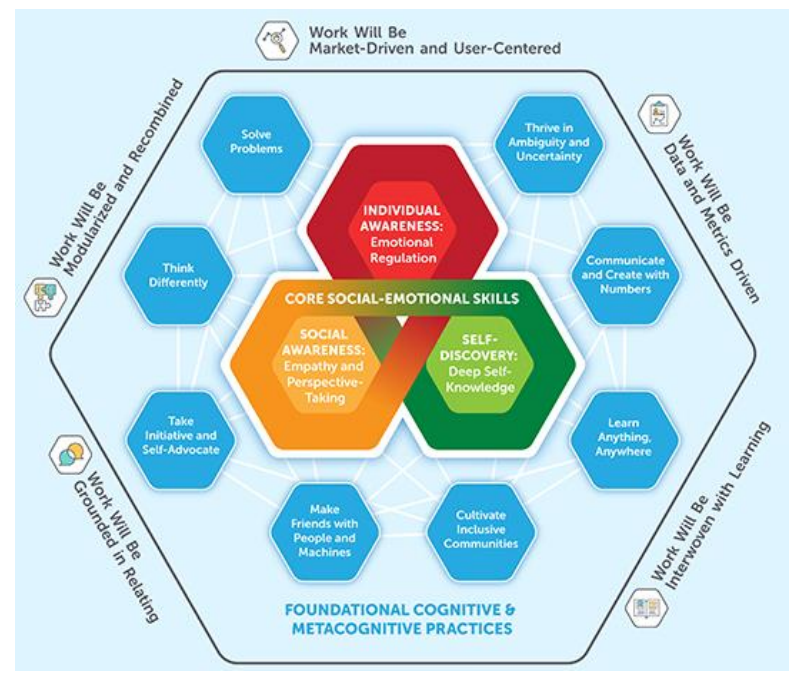

Source: Knowledge Works Foundation (2017) 
Prince, Saveri \& Swanson (2017) identified the core social-emotional skills as selfdiscovery, individual awareness and social awareness. The deep self-knowledge pertains to the ability of the person to discover his own personal and professional strengths, weaknesses, passion and emotional patterns. Meanwhile, individual awareness refers to the ability to recognize own emotions and the triggers that create them. Lastly, the social awareness pertains to building social relations for learning, collaboration and innovation. All these are associated with specific skills, qualities and characteristics.

The current study assessed the college readiness in three areas of academic, social and emotional aspects. These are anchored on the Conley's model of college and career readiness (academic) and the new foundation for readiness (social and emotional).

\subsection{Assessment of college readiness}

According to Conley (2007), academic preparedness refers to 'academic knowledge and skills that students need to succeed in doing college-level work.' If students are collegeready, they make the right decision on their future career before they enter college (Jaime, 2017). College readiness is not simply about academic aspects and the student's resume and profile. If the student is more academically prepared to enter college, he will have a good opportunity to finish a college degree (ACT Research and Policy, 2013). The National Center for Public Policy and Higher Education (2009) identified the K-12 academic indicators such as GPA which can predict college attendance, persistence to graduation and course performance.

Several studies identified the variables associated with academic knowledge and skills. For instance, Palafox, Lorenzo \& Palafox (2018) identified on the employability skills and entrepreneurial skills which the $\mathrm{ABM}$ students were assessed most proficient. Meanwhile, Nasrullah \& Khan (2015) emphasized on the significance of time management that highly influences student's general performance and achievements. Huy (2015) capitalized on writing skills which most of the college students in business struggle. Another important academic skill is reading. As to Umali (2013), student's attitudes towards reading may also influence and affect their reading comprehension performance.

In a study conducted by Ridenour (2015), it was emphasized that qualities needed to enter college is psychological in nature. For this, Felton (2016) argues that 'while test scores 
INTERNATIONAL JOURNAL OF EDUCATIONAL MANAGEMENT AND

DEVELOPMENT STUDIES

Volume 1, Issue 2 • December 2020 • ISSN 2719-0633 (PRINT) 2719-0641 (ONLINE)

predict academic success, self-management and relationship skills may better prepare student to thrive and graduate.' In this, the social-emotional development comes into picture. According to Collaborative for Academic, Social and Emotional Learning (CASEL) in the United States, it is "the process through which children and adults acquire and effectively apply the knowledge, attitudes and skills necessary to understand and manage emotions, set and achieve positive goals, feel and show empathy for others, establish and maintain positive relationships and make responsible decisions." Additionally, Johnson \& Wiener (2017), refer this broad term to 'the many ways that educators and researchers define the work to support students to develop as individuals and in relationship to others.' The CASEL identifies the five essential aptitudes in social-emotional aspects as self-management, self-awareness, responsible decision-making, relationship skills, and social awareness.

Studies on social-emotional preparedness of students identified several concerns. In the study of Pittman (2017), it was confirmed that social and moral development of the students will equitably and diversely lead to a healthier environment. A similar study conducted by Venkatesan (2020) in the USA found that the social-emotional constructs of self-management, growth mindset, self-efficacy, and social-awareness positively predicted GPA and completion. Walton \& Cohen (2011) found a strong relations between academic outcomes and the students' sense of belonging which was supported by Yeager et al. (2016) that even for college students, sense of belonging predicted persistence, academic ability and intelligence quotient.

Most of the students believe that good character traits and behavior are essential qualities and go beyond academic skills which include self-management, discovery of self and mind-set. Relatively, Jawad (2017) examined the students' perception on college preparedness which found that cognitive skills and academic behavior are two factors to adjust to their college life. However, the ability of the students to adjust to the social demands of culture in higher education is found limited. As to the social demands, Sulaiman et al. (2016) emphasized on teamwork as an essential soft skill. The study found that teamwork added-values on students, improve their self-confidence and help develop their skills in communication and relationship with others.

Nagaoka et al. (2013) added on vital contributions of non-cognitive factors in the college readiness of students. To this, Igoe (2017) highly emphasized emotional preparedness 
as the skills to develop his full potential in college and beyond. For example, resilience develops students' ability to handle life's challenges and still find ways to survive. In addition, emotional preparedness encompasses soft skills, including communication, confidence, humility, empathy and maturity. Stoltzfus (2015) found in a study that students who feel less emotionally ready for college compared to other students are likely to have lower grades and other depressing experiences on their campus. Another concept of emotional preparedness was highlighted by Florence (2017) as self-efficacy and autonomy which emerged as positive and negative. The former was characterized by Laryea, Saani \& Dawson-Brew (2014) as positively perceived by students but not directly predict academic performance. The latter, on the other hand, was emphasized by Rowe et al. (2016) as part of the teachers' goal-setting which helps improve the student's academic commitment.

Several other studies emphasized statistical differences in the college preparedness of the students based on their demographic profile. For example, Cuy \& Salinas (2019) found a very high level of readiness in female than the male respondents of HUMSS. Similarly, Kinzie et al. (2007) found that female students participate more often than the male students in educationally focused activities and programs. However, it was found that the type of school or university has no relationship with gender differences in engagement. In terms of the social-emotional preparedness, Venkatesan (2020) in the USA found that the socialemotional constructs of a female student positively predicted higher GPA and greater chances of completion whereas the socio-economic status was significantly associated with and also emerged as a risk factor in GPA and completion. For Khattab (2015), the higher aspirations and higher school achievement of the students are the predictors of future educational behavior. This explains a difference in the academic performance of students in various programs. Dauz (n.d.) found that there is a significant difference in the academic performance of ABM and non-ABM senior high school graduates where the former has higher academic performance than the latter. It was also evident that there is a positive correlation between the academic performance in high school and the academic performance in college. In terms of order of birth, Dominguez (2015) found that the first generation students perceive that their families are thinking that their work is more important than going to college. Moreover, a significant 
INTERNATIONAL JOURNAL OF EDUCATIONAL MANAGEMENT AND

DEVELOPMENT STUDIES

Volume 1, Issue 2 • December 2020 • ISSN 2719-0633 (PRINT) 2719-0641 (ONLINE)

difference was found in academic preparation, where the first generation students were found to have lesser academic preparation.

\section{Methodology}

This study utilized the descriptive method of research to evaluate the academic, social and emotional preparedness of the 255 first year college students pursuing Accountancy, Business and Management in one of the universities in Batangas City, Philippines.

\subsection{Sample size}

The sample size of 255 comprised the $91 \%$ of the total 280 first year students during the second semester academic year 2018-2019. The student-respondents were randomly chosen during the actual data gathering. Whoever present during the actual survey became part of the study. The demographic profile of the student-respondents (Appendix A) in terms of sex, age, general weighted average (GWA), type of school, order of birth and monthly family income showed that they are mostly last born female, graduate of a private school with a GWA of 90 to 94 and an average monthly income of PhP21,000 to PhP30,000.

\subsection{Data Gathering Process}

After thorough reading of literatures, the researcher designed a questionnaire. The first part comprised the profile of the respondents while the second part focused on the selfevaluation of the academic, social and emotional preparedness in entering college. The questionnaire was a checklist form in a 4-scale Likert style. The questionnaire was validated by ten faculty members in the Accountancy, Business and Management track. Their suggestions and recommendations were incorporated to improve the questionnaire.

The survey was conducted with the approval of the dean. The researcher personally handover the questionnaire to the student-respondents during their respective classes. The students were given 15 to 20 minutes to answer and retrieval thereafter.

Frequency and percentage were used to determine the number of responses for each item and was summarized accordingly in tabular form. Weighted Mean was used to evaluate the level of academic, social and emotional preparedness using the average score of the students in the Likert scale. Independent t-test and One-way analysis of variance were used to determine the significant difference on academic, social and emotional preparedness of the students when they are grouped according to the student-respondent's demographic profile. The statistical process aimed to prove that academic, social and emotional preparedness of 
the students have no significant difference when grouped according to their demographic profile.

\section{Results and Discussion}

\section{Table 1}

Level of academic preparedness in pursuing $A B M$

\begin{tabular}{|c|c|c|c|}
\hline Indicators & $\overline{\boldsymbol{X}}$ & SD & VI \\
\hline I can read up to 200 pages of business book in a week. & 2.25 & 0.290 & MP \\
\hline I have a system for taking notes in business subjects. & 2.74 & 0.057 & $\mathrm{P}$ \\
\hline I can write a 10-page or more organized business paper. & 2.35 & 0.219 & MP \\
\hline I have a system for preparing before the business tests and exam & 2.78 & 0.085 & $\mathrm{P}$ \\
\hline I can clearly summarize a college level business reading assignment. & 2.54 & 0.085 & $\mathrm{P}$ \\
\hline $\begin{array}{l}\text { I know my academic strengths in accountancy, business and } \\
\text { management and Customs Adm. subjects. }\end{array}$ & 2.84 & 0.127 & $\mathrm{P}$ \\
\hline $\begin{array}{l}\text { I have a system for scheduling and managing my time in studying } \\
\text { business subjects. }\end{array}$ & 2.82 & 0.113 & $\mathrm{P}$ \\
\hline $\begin{array}{l}\text { I have a system for keeping track of my business projects, business } \\
\text { books and business papers. }\end{array}$ & 2.78 & 0.085 & $\mathrm{P}$ \\
\hline $\begin{array}{l}\text { I have the strategy to complete tasks in Accountancy, business and } \\
\text { management that I find boring. }\end{array}$ & 2.76 & 0.071 & $\mathrm{P}$ \\
\hline $\begin{array}{l}\text { I have the ability to complete all the steps of a business project in a } \\
\text { timely manner. }\end{array}$ & 2.78 & 0.085 & $\mathrm{P}$ \\
\hline Composite Mean & 2.66 & & $\mathbf{P}$ \\
\hline
\end{tabular}

Legend: $3.50-4.00=$ Very Prepared $2.50-3.49=$ Prepared $; 1.50-2.49=$ Moderately Prepared $; 1.00-1.49=$ Not Prepared

The level of academic preparedness in Table 1 has a composite mean of 2.66 interpreted as 'Prepared'. The various study skills and habits were self-assessed by the students, of which 8 of the 10 statements were prepared, topped by their knowledge of their academic strengths with a 2.84 weighted mean. The students were also skillful in scheduling and managing time (2.82), preparation before the business tests and exam (2.78), keeping track of my business projects, business books and business papers (2.78) and preparation of a business project in a timely manner (2.78). However, reading and writing were rated moderately prepared with 2.35 and 2.25 weighted means on writing 10-page business paper and reading 200 pages business book, respectively.

The ABM strand prepared the students for the corporate world with focus on subjects such as Business Math, Applied Economics, Organization and Management and Accounting. 
INTERNATIONAL JOURNAL OF EDUCATIONAL MANAGEMENT AND

DEVELOPMENT STUDIES

Volume 1, Issue 2 • December 2020 • ISSN 2719-0633 (PRINT) 2719-0641 (ONLINE)

Although students are expected to be proficient on numerical, leadership, communication and interpersonal skills, they need also to show proficiency on various study habits and skills. While Palafox, Lorenzo \& Palafox (2018) perceived that ABM students are most proficient in entrepreneurial skill than numerical skills, the results of the current study showed otherwise. On a positive note, the students showed strong self-awareness as they recognized their academic strengths. However, there seems to be contrast with the identified potential weakness in reading and writing. While students are recognizing that the strand is their area of strength, their lack of vital skills in accounting and business particularly reading and writing is a critical issue to be addressed. While Nasrullah \& Khan (2015) affirmed the importance of time management in improving academic performance, Umali (2013) and Huy (2015) embarked on reading and writing. Umali (2013) further stressed the teachers skills in reading is a significant factor in the learning process of the students. Meanwhile, Huy (2015) identified the deficiency of vocabulary words as the main problem in the writing of the students.

\section{Table 2}

Level of social preparedness in pursuing $A B M$

\begin{tabular}{|c|c|c|c|}
\hline Indicators & $\bar{X}$ & SD & VI \\
\hline $\begin{array}{l}\text { I have my family's support in entering college life with Accountancy, } \\
\text { Business and Management track. }\end{array}$ & 3.43 & 0.134 & $\mathrm{P}$ \\
\hline $\begin{array}{l}\text { My fellow students who also engaged in similar learning experiences are } \\
\text { good source of collaborative learning. }\end{array}$ & 3.16 & 0.057 & $\mathrm{P}$ \\
\hline $\begin{array}{l}\text { The school officials provide source of mentorship, advice, information and } \\
\text { feedback. }\end{array}$ & 3.15 & 0.064 & $\mathrm{P}$ \\
\hline $\begin{array}{l}\text { I can identify the social support which I need to be successful in college } \\
\text { life. }\end{array}$ & 3.17 & 0.049 & $\mathrm{P}$ \\
\hline $\begin{array}{l}\text { My family and friends serve as my career influences in my college } \\
\text { preparedness and career motivations. }\end{array}$ & 3.28 & 0.028 & $\mathrm{P}$ \\
\hline My family supports issues on financial concerns in attending college. & 3.33 & 0.127 & $\mathrm{P}$ \\
\hline $\begin{array}{l}\text { My high school educational experiences helped me in my preparedness for } \\
\text { college life. }\end{array}$ & 3.15 & 0.064 & $\mathrm{P}$ \\
\hline $\begin{array}{l}\text { I am enrolled in a school which has a system, standards and culture } \\
\text { appropriate for college life. }\end{array}$ & 3.31 & 0.049 & $\mathrm{P}$ \\
\hline $\begin{array}{l}\text { Social support from parents, mentors and peers are helpful in attaining } \\
\text { diverse set of skills needed for college success. }\end{array}$ & 3.30 & 0.042 & $\mathrm{P}$ \\
\hline $\begin{array}{l}\text { I am provided with Freshmen Orientation program to enhance the } \\
\text { likelihood of college academic success. }\end{array}$ & 3.17 & 0.049 & $\mathrm{P}$ \\
\hline
\end{tabular}


INTERNATIONAL JOURNAL OF EDUCATIONAL MANAGEMENT AND

DEVELOPMENT STUDIES

Volume 1, Issue 2 • December 2020 • ISSN 2719-0633 (PRINT) 2719-0641 (ONLINE)

\begin{tabular}{c|c|c|c}
\hline COMPOSITE MEAN & $\mathbf{3 . 2 4}$ & P \\
\hline Legend: $3.50-4.00=$ Very Prepared $2.50-3.49=$ Prepared $1.50-2.49=$ Moderately Prepared $1.00-1.49=$ Not
\end{tabular}
Prepared

Table 2 showed that students are socially prepared in pursuing the ABM track with a composite mean of 3.24. The indicators assessed include activities conducted within the campus as well as the family and community engagements. Of all the indicators, family and school environment were the factors for preparedness indicated by a 3.43 weighted mean on family's support with ABM track, 3.31 weighted mean on family's financial support and 3.31 weighted mean on appropriate school system. These factors coincide with the study of Hernandez (2011) and Jawad (2017).

The study points on the factors associated with the family, peers and school community as the bases for the students' preparedness. As emphasized by Felton (2016) that relationship skills help students to graduate, the students' self-perception, although shows prepared, calls for a big space for improvement. Although the students recognized their family as a big factor in their preparedness, the role of peers and school environment is equally important in shaping their academic progression. As Venkatesan (2020) found that social-emotional constructs were good predictors of GPA and completion, the students in the current study self-assessed a shortfall on the amount of social constructs needed to establish success in their college life. For example, the least factors identified which are the roles of school officials and the high school educational experience both pertain to a concern on the educational management. As White (2016) posited that higher education don't consider themselves responsible, the schools even don't provide sufficient experience to make students wellprepared for college. Similarly, the observation of Jawad (2017) that the ability of the students to adjust to the social demands of culture in higher education is found limited could remain true in this case. This comes the suggestion of Sulaiman et al. (2016) on the value of teamwork as an essential soft skill. In this sense, both the college and the school have high responsibility in preparing student who are ready with college and career. This shared responsibility involve a higher dose of academic and non-academic activities and programs in order for students to take space in the school community and the society as a whole.

The students' emotional preparedness, as summarized in Table 4, showed a composite mean of 3.16 with a verbal interpretation of 'prepared'. The students have focused goal (3.24), positive relations with peers (3.20), friends and peers to boost self-esteem (3.19) 
INTERNATIONAL JOURNAL OF EDUCATIONAL MANAGEMENT AND

DEVELOPMENT STUDIES

Volume 1, Issue $2 \cdot$ December 2020 • ISSN 2719-0633 (PRINT) 2719-0641 (ONLINE)

and ethical and responsible decisions (3.19). These were similar to the study of Rowe et al. (2016), Sulaiman et al. (2016), Laryea, Saani \& Dawson-Brew (2014) and Zhang (2017).

\section{Table 4}

Level of emotional preparedness in pursuing business track

\begin{tabular}{|c|c|c|c|}
\hline Indicators & $\overline{\boldsymbol{X}}$ & SD & VI \\
\hline $\begin{array}{l}\text { My friends and peers boost my self-esteem and enhanced my emotional } \\
\text { wellbeing in entering college life. }\end{array}$ & 3.19 & 0.021 & $\mathrm{P}$ \\
\hline $\begin{array}{l}\text { I am learning to cope with school's environment and its intellectual and social } \\
\text { demand to preserve my psychological wellbeing. }\end{array}$ & 3.16 & 0.000 & $\mathrm{P}$ \\
\hline I have a clear self-concept to accept challenges in college life. & 3.14 & 0.014 & $\mathrm{P}$ \\
\hline I have a focused goal which serves as my inspiration to succeed. & 3.24 & 0.057 & $\mathrm{P}$ \\
\hline $\begin{array}{l}\text { I have self-advocacy where I am able to speak up for my needs and to seek help } \\
\text { when necessary in the school. }\end{array}$ & 3.06 & 0.071 & $\mathrm{P}$ \\
\hline I have self-awareness where I recognize my emotions and values. & 3.17 & 0.007 & $\mathrm{P}$ \\
\hline $\begin{array}{l}\text { I am practicing self-management where I manage my emotions and behaviors } \\
\text { to achieve my goals. }\end{array}$ & 3.13 & 0.021 & $\mathrm{P}$ \\
\hline I practice social awareness where I show understanding and empathy. & 3.18 & 0.014 & $\mathrm{P}$ \\
\hline $\begin{array}{l}\text { I am forming positive relationships with peers, I work in teams and I am } \\
\text { dealing directly with challenges and conflict. }\end{array}$ & 3.20 & 0.028 & $\mathrm{P}$ \\
\hline $\begin{array}{l}\text { I make ethical and responsible decisions about my personal, academic, social } \\
\text { and emotional behavior. }\end{array}$ & 3.19 & 0.021 & $\mathrm{P}$ \\
\hline COMPOSITE MEAN & 3.16 & & $\mathbf{P}$ \\
\hline
\end{tabular}

Legend: $3.50-4.00=$ Very Prepared $2.50-3.49=$ Prepared $; 1.50-2.49=$ Moderately Prepared $; 1.00-1.49=$ Not Prepared

There are several areas of concern on the emotional development of these students. Although they have rated themselves prepared for the emotional constructs of college life, the amount of academic and non-academic pressures in the college level might overthrow their drive to succeed in their chosen path. For example, the lowest rated variables on selfadvocacy and self-management point out a lack of strong focus among the students. There are numerous distractions and pressures that can be associated to it but the mere lack of focus can result to non-commitment and non-engagement. However, the students' strong adherence to their goal - that is finished their studies - showed another strong contradiction on the results. In addition, the students association of their emotional strength to their peers reflected by their assessment of the working in teams and role of peers in their self-esteem, 
INTERNATIONAL JOURNAL OF EDUCATIONAL MANAGEMENT AND

DEVELOPMENT STUDIES

Volume 1, Issue 2 • December 2020 • ISSN 2719-0633 (PRINT) 2719-0641 (ONLINE)

can be both positive and negative depending on the nature of and the social environment they are in. As Stoltzfus (2015) found that emotionally unprepared students have lower grades, the results of the current study show otherwise. To this, the observation of Rowe et al. (2016) that teachers' goal-setting helps improve the student's academic commitment will have strong impact.

\section{Table 5}

Test of significant difference according to the demographic profile

\begin{tabular}{l|llc|lcl}
\hline & \multicolumn{3}{|c|}{ Age } & \multicolumn{3}{c}{ Sex } \\
\hline Variables & p-values & t-values & VI & p-values & t-values & VI \\
Academic & 0.792 & 0.233 & Not Significant & 0.21 & -1.256 & Not Significant \\
Social & 0.904 & 0.101 & Not Significant & 0.034 & -2.127 & Significant \\
Emotional & 0.45 & 0.802 & Not Significant & 0.25 & -1.152 & Not Significant \\
\hline & \multicolumn{3}{c|}{ Type of School } & \multicolumn{4}{c}{ GWA } \\
\hline Academic & 0.951 & -0.062 & Not Significant & 0.000 & 10.774 & Significant \\
Social & 0.179 & -1.349 & Not Significant & 0.000 & 9.816 & Significant \\
Emotional & 0.943 & 0.072 & Not Significant & 0.000 & 7.59 & Significant \\
\hline & \multicolumn{7}{|c|}{ Family Income } & \multicolumn{3}{c}{ Order of Birth } \\
\hline Academic & 0.249 & 1.357 & Not Significant & 0.272 & 1.308 & Not Significant \\
Social & 0.224 & 1.432 & Not Significant & 0.958 & 0.104 & Not Significant \\
Emotional & 0.346 & 1.123 & Not Significant & 0.134 & 1.879 & Not Significant \\
\hline
\end{tabular}

* Significant at $<0.05$

The summary of the demographic profile (Appendix A) shows variability on the measured factors. Accordingly, there is a higher ratio of female to male; the former with $72.5 \%$ while the latter with $27.5 \%$ only. Of the 255 participants of the study, $87.5 \%$ are within the age range of 18 to $19,11 \%$ within 20 to 21 age range and $1.6 \%$ with age of 22 and above. As to the students' high school General Weighted Average, 47.1\% obtained 90 to 94, $36.9 \%$ garnered 85 to $89,11 \%$ got an excellent mark of 95 to 99 and only $5.1 \%$ got an average performance of 80 to 84 . These grades are numerical distribution of the students' capacity to comprehend and achieve satisfactory performance on their subject assessments during high school. Meanwhile, $91.8 \%$, of the students are graduates from the various private schools in the region. Only, $8.2 \%$ came from the public schools. In the order of birth, $32.5 \%$ of the students are last born. In a close gap are the middle child and first born as the second and third ranks with $29.4 \%$ and $28.2 \%$, respectively. There are $9.8 \%$ students born as only child. The social status is considered diverse as reflected by their average family income. The 
INTERNATIONAL JOURNAL OF EDUCATIONAL MANAGEMENT AND

DEVELOPMENT STUDIES

Volume 1, Issue 2 • December 2020 • ISSN 2719-0633 (PRINT) 2719-0641 (ONLINE)

distribution leans to a modest family income with $34.9 \%$ of the student-respondents earning an average of $\mathrm{PhP} 21,000$ to $\mathrm{PhP} 30,000$ monthly. This is followed by $21.6 \%$ with an average monthly earnings of $\mathrm{PhP} 16,000$ to $\mathrm{PhP} 20,000$. Some $17.6 \%$ earns only $\mathrm{PhP} 11,000$ to $\mathrm{PhP} 15,000$ monthly. The lowest percentages are at the extremes with $15.7 \%$ earning the highest of PhP31,000 and above while 10.2\% earns PhP10,000 and below. While these students were born with an average monthly income, it is remarkably that majority of them studied in private schools where costs of education is extremely high.

In terms of the measure of significant difference, Table 5 shows the summary of the statistical test in terms of age, sex, type of school, GWA, family income and order of birth. The test of difference using ANOVA proved that the academic, social and emotional preparedness of the students have no significant difference when grouped according to age, type of school, family income and order of birth. However, social preparedness was statistically significant in terms of sex which was indicated by a p-value of 0.034 as against the t-value of -2.127 . The data further revealed no significant difference in academic and emotional preparedness. In addition, the GWA of the students showed statistical significance in all the three variables of preparedness. All the three variable got a p-value of .000 as against their computed f-values of 10.774 (academic), 9.816 (social) and 7.59 (emotional).

The identified predictors of preparedness such as GWA and sex are similar to the studies of Cuy \& Salinas (2019), Kinzie et al. (2007), Venkatesan (2020) and Khattab (2015). Similar to Cuy \& Salinas (2019), female students have strong social readiness than male students of ABM which also affirms that of Kinzie et al. (2007) that female students have more social participation than male students. In addition, the GWA of the students clearly predicted their level of preparedness as emphasized by Venkatesan (2020) and Khattab (2015). The statistical results also coincide with the study of Heo (2018) that age has no significant relations with self-directed learning readiness but contradicts the studies of Dominguez (2015) that family perception has significant relations with perception on college studies, Kean (2005) that socio-economic status has direct significant effect on the academic achievement of student and McNally \& Yuen (2015) that there is statistical relationship between order of birth and college GPA.

\section{Conclusion}


INTERNATIONAL JOURNAL OF EDUCATIONAL MANAGEMENT AND

DEVELOPMENT STUDIES

Volume 1, Issue 2 • December 2020 • ISSN 2719-0633 (PRINT) 2719-0641 (ONLINE)

Through self-perception of the 255 randomly selected first year ABM students, the academic, social and emotional college preparedness were quantitatively assessed. A selfmade questionnaire in a 4-scale Likert style was used to gather the data. Based on the evaluation, the students were college-prepared academically, socially and emotionally. However, there are various constructs of their academic and social-emotional preparedness that need to be improved.

The statistical test of difference showed that the demographic profile in terms of age, type of school, family income and order of birth registered no significant difference in the various constructs of academic, social and emotional preparedness. There was a significant difference shown in the respondents' sex and social preparedness but not on academic and emotional preparedness. Similarly, there was significant difference in the various constructs of academic, social and emotional preparedness in terms of the students' GWA in high school. The hypothesis was partially rejected in terms of GWA and sex and accepted in terms of age, type of school, family income and order of birth.

The fact that the high school performance is a good predictor of college-ready students, the role of high school is indeed very vital in their academic success. However, it should be a shared responsibility of the school and the college. For this, strategies should be utilized while students are still in their high school concurrent with the college preparedness program for first year students. This can also be linked to the college website containing the pertinent course information such as the curriculum guide, college preparation checklist, important presentations, learning activities and evaluation tool that can be used as feedback for the success of the college preparation program. In the teaching and learning, collaborative learning strategies may be utilized combining male and female students in a group work with strong focus on developing writing and reading skills. The value of academic and nonacademic advising may also thresh out student difficulties. Departmental focus should be on providing academic and non-academic organizations for the students to join to improve their social preparedness.

As the current study posed a big question mark on the real preparedness of the students in their college and future career, the program management as well as high school administration need to be more accountable on developing a future ready individual. To 
INTERNATIONAL JOURNAL OF EDUCATIONAL MANAGEMENT AND

DEVELOPMENT STUDIES

Volume 1, Issue 2 • December 2020 • ISSN 2719-0633 (PRINT) 2719-0641 (ONLINE)

prepare them for college alone is insufficient to give them a better career after their academic journey. A college-ready student should complete a degree with a life-ready perspectives.

\section{Appendix A}

Demographic Profile of the Student-Respondents

\begin{tabular}{|c|c|c|c|c|c|}
\hline \multicolumn{3}{|c|}{ Sex } & \multicolumn{3}{|c|}{ Type of School } \\
\hline & $\mathrm{F}$ & $\%$ & & $\mathrm{~F}$ & $\%$ \\
\hline Male & 70 & 27.5 & Private & 234 & 91.8 \\
\hline Female & 185 & 72.5 & Public & 21 & 8.2 \\
\hline \multicolumn{3}{|c|}{ Age } & \multicolumn{3}{|c|}{ Order of Birth } \\
\hline 17 years and below & 0 & 0 & First Born & 72 & 28.2 \\
\hline $18-19$ & 223 & 87.5 & Middle child & 75 & 29.4 \\
\hline $20-21$ & 28 & 11 & Last born & 83 & 32.5 \\
\hline 22 and above & 4 & 1.6 & Only child & 25 & 9.8 \\
\hline \multicolumn{3}{|c|}{ GWA } & \multicolumn{3}{|c|}{$\begin{array}{c}\text { Monthly Family Income } \\
\end{array}$} \\
\hline $75-79$ & 0 & 0 & Php 10,000 below & 26 & 10.2 \\
\hline $80-84$ & 13 & 5.1 & $11,000-15,000$ & 45 & 17.6 \\
\hline $85-89$ & 94 & 36.9 & $16,000-20,000$ & 55 & 21.6 \\
\hline $90-94$ & 120 & 47.1 & $21,000-30,000$ & 89 & 34.9 \\
\hline $95-99$ & 28 & 11 & 31,000 above & 40 & 15.7 \\
\hline
\end{tabular}

\section{References}

ACT Research and Policy (2013). Readiness Matters: The Impact of College Readiness on College Persistence and Degree Completion. Available online at www.act.org. Accessed on August 2020.

Boden, K. (2011). Perceived Academic Preparedness of First-Generation Latino College Students. Journal of Hispanic Higher Education, 10, 96-106. DOI: 10.11771538192711402211

Conley, D. T. (2007). College Readiness Practices At 38 High Schools and the Development Of The College Career Ready School Diagnostic Tool. Eugene, OR: Education Policy Improvement Center.

Cuy, N.A. \& Salinas, E.M. (2019). Aspiration and Readiness of Filipino Senior High School Students In Pursuing College Degree. Open Journal Of Social Sciences. 7, 143-152. Https://Doi.Org/10.4236/Jss.2019.75012

Dauz, F. (n.d.). Preparedness Of Senior High School Graduates Leading To The Bachelor of Science In Accountancy Program: A Correlational Study. A Thesis Presented To The Faculty Of The Holy Angel University Master of Science In Accountancy.

Deangelo, L., \& Franke, R. (2016). Social Mobility and Reproduction for Whom? College Readiness and First-Year Retention. American Educational Research Journal, 53, 1588- 1625. DOI: 10.3102/0002831216674805 
INTERNATIONAL JOURNAL OF EDUCATIONAL MANAGEMENT AND

DEVELOPMENT STUDIES

Volume 1, Issue 2 • December 2020 • ISSN 2719-0633 (PRINT) 2719-0641 (ONLINE)

Department Of Education (2012). The K to 12 Basic Education Program.

Dominguez, R. (2015). Perceived Barriers to Higher Education among First-Generation and Non-First-Generation Latino Male High School Students. [Online] Pp.1-35. Available

At: Https://Scholarlyrepository.Miami.Edu/Cgi/Viewcontent.Cgi?Article=2419\&CoNtext $=$ Oa_Dissertations.

Felton, E. (2016). When Social and Emotional Learning Is Key to College Success. Education. The Atlantic.

Florence, K.M. (2017). Understanding College Preparedness of First-Semester College Students. UNLV Theses, Dissertations, Professional Papers, and Capstones. 2972. https://digitalscholarship.unlv.edu/thesesdissertations/2972

Grundmeyer, T. A. (2012). A Qualitative Study of the Perceptions of First Year College Students Regarding Technology And College Readiness. Graduate Theses and Dissertations. 12599. Https://Lib.Dr.Iastate.Edu/Etd/12599

Heo, J. \& Han, S. (2017). Effects of Motivation, Academic Stress and Age In Predicting SelfDirected Learning Readiness (SDLR): Focused On Online College Students. Education and Information Technologies, [Online] 23(1), Pp.61-71. Available At: $\quad$ Https://Link.Springer.Com/Article/10.1007/S10639-017-95852\#Citeas.

Huy, N. (2015). Problems Affecting Learning Writing Skill Of Grade 11 At Thong Linh High School. Asian Journal Of Educational Research, 3(2), Pp.53-67.

Igoe, K. (2017). Emotional Readiness and How to Obtain It. Collegevine. Available online at https://blog.collegevine.com/emotional-readiness-and-how-to-obtain-it

Jaime (2017). College Readiness: The Importance Of Preparing For College While In High School. Reality Changers. Available online at: https://realitychangers.com.

Jawad, L.H. (2017). Examining College Readiness In An Early College Program That Focuses On Health Careers: Perceptions Of Graduating Students. A Dissertation submitted to the University of Michigan-Dearborn.

Johnson, H. \& Wiener, R. (2017). This Time, With Feeling Integrating Social and Emotional Development and College- and Career-Readiness Standards. Aspen Education \& Society Program.

Khattab, N. (2015). Students' Aspirations, Expectations and School Achievement: What Really Matters? British Educational Research Journal. 41, 731-748. Https://Doi.Org/10.1002/Berj.3171

Kinzie, J., Gonyea, R., Kuh, G., Umbach, P., Blaich, C. \& Korkmaz, A. (2007). The Relationship Between Gender And Student Engagement In College. [Online] Pp.2-23. Available

At: Https://Pdfs.Semanticscholar.Org/8352/7135f260de6eda03bdc30c7bb9130713e813.P df.

Laryea, J., Saani, A. \& Dawson-Brew, E. (2014). Influence of Students Self-Concept on Their Academic Performance in the Elmina Township. European Journal of Research and Reflection in Educational Sciences, 2 (4), Pp.1-9.

Mcnally, E. \& Yuen, E. (2015). The Effects of Birth Order on Academic Success. Acta Spartae, 1(1), Pp.16-18. 
Nagaoka, J., Farrington, C.A., Roderick, M., Allensworth, E., Keyes, T.S., Johnson, D.W. \& Beechum, N.O. (2013). Readiness For College: The Role Of Non-Cognitive Factors And Context. Voices In Urban Education, 38, 45-52.

Nasrullah, S. And Khan, M. (2015). The Impact of Time Management on the Students' Academic Achievements. Journal of Literature, Languages and Linguistics, 11, Pp.6671.

Palafox, Q., Lorenzo, T., \& Palafox, L. (2018) Perceptions of the Senior High School Students on their Employability Skills. DLSU Research Congress 2018.

Ridenour, M. J. (2015). How Do College Students Define College Preparedness? School of Education Student Capstone Theses and Dissertations. 231. https://digitalcommons.hamline.edu/hse all/231

Rowe, D. A., Mazzotti, V. L., Ingram, A., \& Lee, S. (2017). Effects of Goal-Setting Instruction on Academic Engagement for Students At Risk. Career Development and Transition for Exceptional Individuals, 40(1), 25-35. ttps://doi.org/10.1177/2165143416678175

Stoltzfus, K. (2015). Students Who Fell Emotionally Unprepared For College Struggle In The Classroom. The Chronicle Of Higher Education.

Sulaiman, M., Mat, Z., Husain, F., Nizah, M., Latiff, L. \& Sulaiman, A. (2016). The Impact of Teamwork Skills on Students in Malaysian Public Universities. The Social Sciences, 12: 1682-1686. DOI: 10.36478/sscience.2017.1682.1686

Umali, J. (2013). Factors Affecting the Reading Comprehension of Selected ACCS of the University Of Makati Students. A Thesis presented to the Faculty of the University of Makati. 